OOPEN ACCESS

International Journal of Applied Research in Social Sciences

P-ISSN: 2706-9176, E-ISSN: 2706-9184

Volume 2, Issue 5, P.No. 111-129, November, 2020

Fair East Publishers

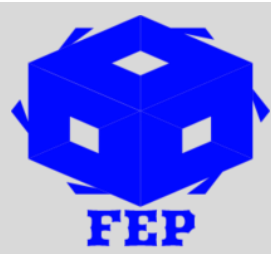

Journal Homepage: www.fepbl.com/index.php/ijarss

\title{
CAREER CHOICES OF SENIOR HIGH TECHNICAL STUDENTS IN THE WA MUNICIPALITY OF GHANA
}

\author{
Justice Agyei Ampofo ${ }^{1,2}$ \\ ${ }^{1}$ University for Development Studies, Tamale (Ghana) \\ ${ }^{2}$ University of Education, Winneba (Ghana)
}

*Corresponding Author: Justice Agyei Ampofo

Corresponding Author Email: papajusty@ gmail.com

Article Received: 28-09-20

Accepted: 05-11-20

Published: 25-11-20

Licensing Details: Author retains the right of this article. The article is distributed under the terms of the Creative Commons Attribution-Non Commercial 4.0 License (http://www.creativecommons.org/licences/by-nc/4.0/) which permits non-commercial use, reproduction and distribution of the work without further permission provided the original work is attributed as specified on the Journal open access page.

\begin{abstract}
Choosing a career can be hard when you have no idea what you want to do. However, there seems to be paucity of studies on career choices among senior high schools' students in Ghana in general and Wa Municipality in particular. This study was intended to find out the career choices of students of Wa Senior High Technical School in the Wa Municipality of the Upper West Region of Ghana. A descriptive survey design was employed for the study. Data was collected from a sample of 80 students and 20 teachers using questionnaire. All respondents responded to the questionnaire. The data were presented in tables and charts and analysed using frequencies and percentages. The study found out that, the students needed career information, employment information, interpersonal needs, educational needs and selfunderstanding. The top career guidance needs of students as expressed by teachers and the school counsellor include educational information, study habits, interpersonal information, educational needs and career needs. The study also found that, the factors that influence students' choice of career are extrinsic and interpersonal factors and they include perception of colleague/peer pressure, teachers' influence, societal perceptions, availability of further training and occupational security. This helps students learn about and explore careers that ultimately lead to career choice. This played a critical role in shaping students career choice. It was recommended that Career Education and Guidance should be introduced in the primary school to enable children to explore the world of work as young people need to make a smooth transition from primary school to the initial years of Senior High School and the Ministry of Education should allocate fund for a Guidance and Counselling activities in all
\end{abstract}


basic and second cycle schools. This will enable the guidance coordinators to function effectively at their various levels of work.

Keywords: Career Choices, Challenges, Senior High Technical School, Students, Wa, Ghana.

\section{INTRODUCTION}

The 2014 educational reforms expects student living the Senior High School to be equipped with knowledge and skills. This knowledge and skills will help them to select a career to enable them attain their career goals that will finally lead to contributing to feeling of adequacy, happiness and success (Attieku, 2006). This means that, the course of action arriving at sound career and educational decisions is directly associated with future, success and fulfillment, but there is no clear process that Senior High Schools have used to make career choices. Senior High School students should have the opportunity to explore all of the choices available in order to make a logical educated plan when choosing a career (Ampofo, 2017).

Searching for a job, career planning and deciding on what to choose play an important role in students career choices (Watts, 2004). Many students are often faced with uncertainty and stress as they make career choices. Many of them do not make adequate research on their own career nor do they receive adequate directions from their school guidance coordinators. Most of them are not aware of what goes into career choice (Amanning, 2009). Many youth go into unsuitable careers due to ignorance, inexperience, peer pressure, advice from friends, parents and teachers or as a result of the prestige attached to certain jobs without adequate vocational guidance and career counselling (Sultana, 2004).

Lawer (2007) assessed the effectiveness of career guidance in Senior High Schools in Kumasi Metropolitan and concluded that majority of students were not aware of major occupation groups in Ghana, knowledge of training and qualification necessary for employment in the various occupations, conditions of work, earning and other rewards of occupation, and did not have better understanding of their career interest, aptitudes and abilities. This clearly shows that the majority of them were not concerned about their future career. This situation compels one to ask whether they are given the needed guidance on available careers relating to the programmes they are pursuing. Are they aware of what goes into career choice? What are their career guidance needs? And what specific factors influence their choice and how do those factors affect them? This study, therefore, seeks to analyse the career guidance needs of form 3 students of Wa Senior High Technical School.

Evidence from Wa Senior High Technical School clearly shows that majority of the students are unable to further their education in the university level. This is manifested in the frequent appeal for change of courses by some of the new entrants to the school. Some of these students spend the whole academic year looking for a course appropriate to them. Another group of students also express dissatisfaction at subjects being pursued at senior high level. So this led students not to give their best academically and has the skills and the potential for the university programme but for one reason or the other find their way into the university. The last group of students was also offering courses that were selected by their parents. These and others not mentioned, shows that the career guidance at Wa Senior High Technical School is not producing the expected outcome hence this study seeks to find out the factors that 
influence choice of careers among Wa Senior High Technical School students, challenges encountered by students in the choice of their careers and the career guidance needs of Senior High School students.

\section{LITERATURE REVIEW}

\section{Vocational/Career Guidance}

According to Pittenger (2003), when students are active participants in the planning process of the career development programmes, they may take a more active role in their own career development. Allowing individuals to contribute to the planning of a programme create a more conducive environment to be active participants in the program as well. Students will likely work harder to accomplish career goals they have set rather than goals set by someone else (Barker, 2000).

A review of the literature has shown that most students entering tertiary institutions in South Africa lack direction in course selection and provide vague reasoning for their chosen course of study (OECD, 2004, Ampofo, 2017). Within the Ghanaian Educational System, there is presently inadequate provision for career guidance or assessment of individual learners. This weakness results in high unnecessary costs for the country and South African businesses, as well as social discontent and hardship (Kankam, 2000).

The importance of career choice among Senior High Technical School students cannot be over emphasised. Students at this level are mainly adolescents who are moving from this stage of development into adulthood hence the need for career guidance for Senior High Technical School students.

\section{Challenges Students Encounter in Making Career Choices}

Decision making can be defined as, "an act of choice by which an executive selects one particular course of action from among possible alternatives for the attainment of a desired end or as a solution to a specific problem." (Ampofo, 2019) It involves conscious or unconscious attempt at making a choice out of competing alternatives. It implies selecting from alternative policies, procedures, and programmes. The following are the challenges students encounter in making career choices:

Career Path Data: Career choice is not always a priority for Senior High School students. For more than a decade, both new and experienced educators have been conscientious of students making poor personal career choices, postponing, and potentially limiting their career successes.

Unavailability of jobs: This is the situation where the available jobs are not enough to cater for the large number of job seekers. Daily Graphic (2011, March 17) stated that the National Youth Employment Programme was established as part of the short-term solution to youth unemployment in the country. Various modules were introduced to offer jobs in community policing, education, health, dressmaking, agriculture road maintenance and ICT.

Job discrimination: This may be in two forms. The first is where employers may discriminate against an employee on the ground of sex, tribe or race rather than on the basis of his or her abilities. The other is where school leavers would not like to work in certain organisations because of poor working condition and others. Kankam (2000) states that, graduates seem to be selective in the type of job they want. Most of them refuse to work in certain places at the going market rate because they do not want such jobs. 
Unawareness of job: When people are not aware of how and where to get job, they end-up jobless or dissatisfied with what they are doing. Often the unemployed are not aware of the opportunities available in other parts of the country or in other occupations. This situation lead to structural unemployment - is caused by a mismatch between labour skills and jobs. Lawer (2007) researched on assessing the effectiveness of career guidance in Senior High Schools in Kumasi Metropolitan and used descriptive survey design. She used both questionnaire and interview. The findings of this research were as follows; majority of Senior High School students in Kumasi Metropolis agreed that career talks were given in the school.

Financial support: This is very common in areas where most parents are not gainfully employed or where income of most parents are so low that they cannot provide money for the training or continuous education of their children. Bernes (2002) posit that there are at least two major ways in which family background can act as barrier to further education. First is family ability to finance extensive schooling.

Inadequate marketable skills: For our students to get job they wish to engage in, there is also the need to have the ability to perform well in those areas. This calls for the right form of training and education. Lack of the right training or education needed for those jobs will render our school leavers unmarketable in the job market (Cob, 2001).

\section{METHODOLOGY}

\section{Research Design}

The study was intended to explore the career guidance needs of Form three (SHS 3) students of Wa Senior High Technical School in the Wa Municipality of the Upper West Region of Ghana and to explore the career guidance needs of the students; a descriptive survey design was employed for the study. A survey is a study that is done by collecting information that will determine or demonstrate relationships and describe situations as they exist. It is done without any prior experiment to know things to manipulate. It is done without influence or interference on any variable to be studied as suggested by Ampofo, 2020.

\section{Study Area}

The study was conducted in Wa Senior High Technical School in the Upper West Region of Ghana. The school was chosen because it is an old school, which has so far attracted limited research on challenges facing students in their career choices and their career needs. Wa Senior High Technical School is one of the best technical schools of the Upper Region in terms of social service development, teacher training facility as well as any school facility specifically for students. The study was conducted in the school because the students have always been complaining about their career choices and career needs that they do not know what to do after completing Senior High School.

\section{The Population}

The target population according to Ampofo (2020) is the entire aggregation of respondents that meet the designated set of criteria. The target population for the study was all the Form Three SHS students in the Wa Senior High Technical School and all the Guidance and Counselling Coordinators and Administrator in the school. The final year students were targeted because they were on the verge of completion to get ready to move into the world of work or further education. These groups of students were chosen because they were more likely to have a career in mind than the others. They would soon complete school and end up determining their career or choose a career without necessarily furthering their education and 
were in better position to respond adequately to the questionnaire. The final year students were the target group from whom the information was sought. The final year students were 300 in all. This population consisted of 169 boys and 131 girls. Of these 140 students offered General Arts, 120 offered Home Economics and 40 offered Technical. Students are the main target for the study and need to be studied.

\section{Sample Size and Sampling Technique}

Ampofo (2019) explains that, 'it is imperative for you to determine an aspect of population to be involved in your study.' A study may entail a large population unlike others with small population. In such situation, a portion of the entire population may be selected for study and this is what is termed as sample. In selecting sample for the study, the researcher made use of stratified and simple random sampling technique in selecting students. Stratified random sampling is a method of sampling that involves the division of a population into smaller groups known as strata. In stratified random sampling, the strata are formed based on members shared attributes or characteristics and simple random sampling was applied within the strata to select the sample for the study.

Stratified sampling was employed in selecting respondents for the study. This was done by the researcher grouping the students into their various programmes/classes and each of them was selected using simple random sampling technique. Simple random sampling means that each member of the sampling population has an equal chance of being selected. It called for a sufficiently large sample to ensure that the sample reflect the population (Ampofo, 2019:2020).

Conceptually, simple random sampling is the simplest of the probability sampling techniques, it requires a complete sampling frame. Advantages are that it is free of classification error, and it requires minimum advance knowledge of the population other than the frame. Its simplicity also makes it relatively easy to interpret data collected via simple random sampling. In all hundred respondents were selected for the study comprising eighty students, nineteen teachers and one guidance and counselling coordinator. This sample size was chosen for the researcher to be able to manage them and also to avoid superficial perspective on the side of the researcher. Students' questionnaires were handed over to students and guided through the questions.

\section{Instruments for Data Collection}

The researcher used a thirty-item questionnaire in collecting data for the research. A questionnaire is a research instrument consisting of series of questions for the purpose of a survey or statistical study. The structured questionnaire type was used. Ampofo (2020) explains that, a structured questionnaire is a data collection instrument which contains predetermined standard questions or items meant to collect numerical data that can be subject to statistical analyses. He explains that the questions are close ended and answers outlined, which gives respondents the opportunity to respond to sample questionnaire questions

The questionnaire was arranged in the following sections. Section A: Personal Information, Section B: Factors that influence choice of careers among Senior High School students, Section C: Challenges encountered in choosing a career and Section D: Career guidance needs of Senior High School students. With the structured questionnaire, the respondents felt more comfortable responding to pre-determined responses than items that require them to express their views and feelings. However, the instrument did not allow the researcher to explore the 
feelings and experience of participants (Ampofo, 2019). On the whole, the pupils responded to thirty questions which were Likert-scale type. However, there were few open ended questions which allowed participants to share their views that were not captured. This was to combat the negative side of the structured questionnaire.

\section{Validity and Reliability of Questionnaire}

Validity in research is the degree of stability exhibited when measurement is repeated under identical conditions. Research validity refers to whether the research actually measured what was supposed to measure and not something else. Reliability means that responses to the questionnaire were consistent (Ampofo, 2019:2020). The researcher took the following steps in order to ensure the validity of the data. The questionnaire was based on information obtained from literature review. This was to ensure that it was a representation of student's education and experiences (Ampofo, 2019). The questions were formulated in simple language for easy understanding. The researcher gave to an expert in guidance and counselling to scrutinize to ensure the validity. Colleagues added some questions and certain aspects of the questionnaire were rephrased for clarity. This helped clarity portions where participants did not understand.

There was also a pilot test conducted to ensure the reliability of instruments at Wa Senior High School in Wa. Twenty students were selected for the pilot exercise. Wa Senior High School was closen for the pilot study because it is close to the study area with the participants having similar characteristics as those in the study area. The responses in the pilot helped to modify certain aspects of the questionnaire before they were administered in the main study.

\section{Data Collection Procedure}

The researcher visited the school and briefed the teachers and students on the purpose of the study and its educational implications. They were allowed some time to raise questions about the areas they could not understand. After the discussion, the questionnaires were distributed to them. The students answered the questionnaire the same day which ensured objectivity. On the whole, the researchers spent one week for the collection of the data. All respondents responded to the questionnaire.

\section{Data Analysis Procedure}

After collecting the data, it was first edited (Ampofo 2020). The edited questionnaires were organized. The work was organized under career guidance needs of students, factors influencing students' choice of career, challenges facing students in their career choices and career needs. It was then coded. The researcher used frequencies and percentages in analyzing the data. These statistical instruments were used because they allow data to be organised for further analysis. It also allows large amounts of raw data to be sorted and reorganised in a neat format. It also allows a dialogue between the test and the exact numbers in the result. Again, the different group classification allows comparison and better understanding of data. However, it is not the best to use in showing trend or relationship between variables (Ampofo, 2020).

\section{Introduction}

\section{RESULTS AND DISCUSSION OF RESULTS}

The purpose of the study was to find out the challenges facing Form Three (SHS 3) students of Wa Senior High Technical School in career choices. This chapter is confined to the 
interpretation of data. In analysing the results of the data collected through the study, the researcher has divided this chapter into the following sub-divisions:

i. Biographical data.

ii. The factors that influence choice of careers among Senior High School students.

iii. The challenges encountered by students in the choice of their careers.

iv. The career guidance needs of Senior High School students.

\section{Biographical Data of Students}

One item of the questionnaire gathered data on the respondents gender which is presented in the table below.

Table 1

Sex Distribution of Respondents

\begin{tabular}{lll} 
Sex & $(\mathbf{F})$ & $\mathbf{( \% )}$ \\
\hline Male & 46 & 57.5 \\
Female & 34 & 42.5 \\
\hline Total & $\mathbf{8 0}$ & $\mathbf{1 0 0}$ \\
\hline \multicolumn{2}{c}{ Source: Field Data, 2016}
\end{tabular}

Table 1 presents the gender of participants (students) who responded to the questionnaire items. From table 1, 80 students were given questionnaire. All students responded to the questionnaire. Out of the 80 students, majority of respondents were males representing $46(57.5 \%)$ of the sample population while their female counterparts recorded $34(42.5 \%)$ of the sample population. The implication is that, the male respondents outnumbered the female respondents.

Another aspect of the questionnaire gathered data on the age distribution of the respondents (students) and this is what Table 2 presents.

Table 2

Age Distribution of Respondents

\begin{tabular}{lll} 
Age Range & $(\mathbf{F})$ & $(\boldsymbol{\%})$ \\
\hline $14-16$ & 17 & 21.2 \\
$17-19$ & 35 & 43.8 \\
20 and above & 28 & 35.0 \\
\hline Total & $\mathbf{8 0}$ & $\mathbf{1 0 0}$ \\
\hline \multicolumn{3}{c}{ Source: Field Data, 2016 }
\end{tabular}

Table 2 presents the ages of students who responded to the questions. The table shows that majority of form 3 students at the Wa Senior High Technical School were between 17 and 19 years representing $35(43.8 \%)$ of the respondents. This was followed by those in the age group 20 years and above who also recorded $28(35 \%)$ and $17(21.2 \%)$ of the respondents were between the age group of 14 and 16. The implication of this is that, majority of form 3 students at the Wa Senior High Technical School were older from 17 years.

Another aspect of the questionnaire gathered data on the programmes offered by the respondents and has been presented in Table 3. 
Table 3

Programmes Offered by Students

\begin{tabular}{lll}
\hline Programmes & $(\mathbf{F})$ & $\mathbf{( \% )}$ \\
\hline Home Economics & 33 & 41.3 \\
General Arts & 40 & 50.0 \\
Technical & 7 & 8.8 \\
& & \\
\hline Total & $\mathbf{8 0}$ & $\mathbf{1 0 0}$ \\
\hline
\end{tabular}

Source: Field Data, 2016

Table 3 shows the various programmes offered by form three students of Wa Senior High Technical School. From the data, it is seen that students various programmes students were represented. The results show that majority 40(50\%) of students studied General Arts, followed by Home Economics 33(41.3\%) and Technical education 7(8.8\%). It is, therefore, clear that majority of students offered General Arts and minority offers Technical courses.

Some aspects of the questionnaire collected information on the choice of programme to pursue after school and has been presented in Table 4.

Table 4

Choice of Programme to Pursue after School

\begin{tabular}{lll}
\hline & $(\mathbf{F})$ & $(\boldsymbol{\%})$ \\
\hline Economics & 14 & 17.5 \\
Business Administration & 19 & 23.8 \\
Law & 10 & 12.5 \\
Medicine & 7 & 8.8 \\
Agricultural Science & 11 & 13.7 \\
Catering & 8 & 10.0 \\
Building and Construction & 11 & 13.7 \\
\hline Total & $\mathbf{8 0}$ & $\mathbf{1 0 0}$ \\
\hline \multicolumn{2}{c}{ Source: Field Data, 2016} &
\end{tabular}

Table 4 show students' choice of programme to pursue after SHS and the results suggests that majority of students preferred to pursue Business Administration at the higher level as 19(23.8\%). Economics was next with 14(17.5\%) and Agricultural Science and Building and Construction followed with 11(13.7\%) each. Law, Catering and Medicine recorded $10(12.5 \%), 8(10 \%)$ and $7(8.8 \%)$ respectively.

\section{Biographic Data of Teachers}

One item of the questionnaire gathered data on the respondents (teachers) gender which is presented in the table below.

Table 5

Sex Distribution of Respondents

\begin{tabular}{|c|c|c|}
\hline Sex & (F) & $(\%)$ \\
\hline Male & 13 & 65 \\
\hline Female & 7 & 35 \\
\hline Total & 20 & 100 \\
\hline
\end{tabular}


The sex distribution of teachers respondents show that majority of respondents were males as males represented as $33(77 \%)$ and only $10(23 \%)$ were females. The implication is that, male teachers outnumbered female teachers.

Another aspect of the questionnaire gathered data on the age distribution of teachers respondents and this is what Table 6 presents.

Table 6

\begin{tabular}{lcc}
\multicolumn{3}{c}{ Age of Respondents } \\
\hline Age Range & $\mathbf{( F )}$ & $\mathbf{( \% )}$ \\
\hline & & \\
$26-36$ & 3 & 15 \\
$37-46$ & 14 & 70 \\
50 Years and above & 3 & 15 \\
\hline Total & $\mathbf{2 0}$ & $\mathbf{1 0 0}$ \\
\hline \multicolumn{3}{l}{ Source: Field Data, 2016}
\end{tabular}

The results form Table 6 shows that majority of respondents were between the age group 3746 representing $14(70 \%)$. Also, 3(15\%) of the respondents were between the age groups 2636 while those from 50 years and above represented $3(15 \%)$ of the respondents. The implication is that, majority of the teachers in Wa Senior High Technical School were older form 37 years.

Some aspects of the questionnaire collected information on the positions of the respondents in Wa Senior High Technical School and has been presented in Table 7.

Table 7

Position of Respondents

\begin{tabular}{lcc}
\hline Position & (F) & $(\boldsymbol{\%})$ \\
\hline Teachers & 19 & 95 \\
Guidance and counselling coordinator & 1 & 5 \\
\hline Total & $\mathbf{2 0}$ & $\mathbf{1 0 0}$ \\
\hline \multicolumn{2}{r}{ Source: Field Data, 2016 } &
\end{tabular}

Table 7 shows that majority of respondents were teachers and they formed 19(95\%) of the respondents while guidance and counselling coordinator were only 1(5\%).

\section{Analysis of Items}

The analyses of the items are based on the three research questions which are as follows:

1. What factors influence choice of careers among students at Wa Senior High Technical School?

2. What are the challenges encountered by students at Wa Senior High Technical School in their choice of careers?

3. What are the career guidance needs of the students of Wa Senior High Technical School?

Research Question 1: What factors influence choice of careers among students at Wa Senior High Technical School?

One aspect of the questionnaire gathered data on the factors that influence choice of careers among students at Wa Senior High Technical School and the relevant data are presented in Table 8, 9 and 10 below. 


\begin{tabular}{lrl}
\hline & $(\mathbf{F})$ & $(\boldsymbol{\%})$ \\
\hline Opportunity to be creative & 31 & 38.75 \\
Issues of Ego & 23 & 28.75 \\
My level of intelligence & 15 & 18.75 \\
My beliefs and ambitions & 11 & 13.75 \\
\hline \multicolumn{3}{c}{} \\
Total & $\mathbf{8 0}$ & $\mathbf{1 0 0}$ \\
\hline \multicolumn{2}{c}{ Source: Field Data, 2016}
\end{tabular}

Table 8 shows the intrinsic factors that influenced students' choice of career. The results show that, among the intrinsic factors opportunity to be creative was the highest recording $31(38.75 \%)$. This was closely followed by Issues of Ego which also recorded 23(28.75\%). The level of intelligence and believes and ambitions also recorded 15(18.75\%) and $11(13.75 \%)$ respectively.

These factors are consistent with Anne Roe's Personality/Need Theory cited in Barker (2000); posit that, one's need is the main determinant of the nature of an individual's interests including vocational interest.

Table 9

Extrinsic Factors

\begin{tabular}{lll}
\hline & $(\mathbf{F})(\boldsymbol{\%})$ \\
\hline Societal perceptions & 24 & 30 \\
Availability of further training & 19 & 23.75 \\
Occupational security & 15 & 18.75 \\
Good remuneration & 13 & 16.25 \\
Good conditions of service & 9 & 11.25 \\
\hline Total & $\mathbf{8 0}$ & $\mathbf{1 0 0}$ \\
\hline \multicolumn{4}{c}{ Source: Field Data, 2016}
\end{tabular}

Extrinsic factors responsible for students' choice of career are presented in Table 9. The result indicates that, among the extrinsic factors, societal perceptions were the highest recording 24(30\%). This is consistent with Donald Super's Developmental/Self-Concept Theory which thinks of vocation in terms of self-perception (Cobb, 2001).

This was followed by the availability of further training and occupational security which also recorded $19(23.75 \%)$ and $15(18.75 \%)$ respectively. The last two extrinsic factors are good remuneration and good condition of service which also recorded $13(16.25 \%)$ and $9(11.25 \%)$.

Table 10

Inter-Personal Factors

\begin{tabular}{lll}
\hline & $(\mathbf{F})$ & $(\boldsymbol{\%})$ \\
\hline Perception of colleagues/peer pressure & 34 & 42.5 \\
Teachers' influence & 25 & 31.25 \\
Family relations & 21 & 26.25 \\
\hline Total & $\mathbf{8 0}$ & $\mathbf{1 0 0}$ \\
\hline \multicolumn{4}{c}{ Source: Field Data, 2016 } &
\end{tabular}


Interpersonal factors contributing to career choice of students are presented in table 10. The result indicates that perceptions of colleagues or peer pressure were the highest recording $34(42.5 \%)$. This was closely followed by the influence of teachers and family relations which also recorded $25(31.25 \%)$ and $21(26.25 \%)$ respectively.

\section{Factors influencing choice of careers among students}

Among all the three factor groups contributing to student career choice, the top five most important factors are presented in Table 11.

Table 11

Factors that influence Students Career choices as Expressed by Students

\begin{tabular}{|c|c|c|c|}
\hline \multirow[b]{2}{*}{ Perception of colleagues/peer pressure } & \multicolumn{2}{|c|}{ Factor relation $(\mathrm{F})$} & \multirow{2}{*}{$\frac{(\%)}{30}$} \\
\hline & Inter-personal & 24 & \\
\hline Teachers' influence & Inter-personal & 17 & 21.25 \\
\hline Societal perceptions & Extrinsic & 15 & 18.75 \\
\hline Availability of further training & Extrinsic & 13 & 16.25 \\
\hline Occupational security & Extrinsic & 11 & 13.75 \\
\hline Total & & 80 & 100 \\
\hline
\end{tabular}

Source: Field Data, 2016

From the responses given, there is an indication that career decisions making is very critical during adolescence. This is why Attieku (2006) states, "choosing a career is perhaps second only to choice of mate in terms of the pervasiveness of the impact on one's life." From the table the most important factors according to ranking are: Perception of colleagues/peer pressure 24(30\%), teachers' influence 17(21.25\%), societal perceptions $15(18.75 \%)$, availability of further training $13(16.25 \%$ ) and occupational security 11(13.75). A closer look at these factors indicates that they are related to interpersonal factors and extrinsic factors.

Looking at the findings on how Senior High School students make their career decisions, the factors affecting career choice of students is consistent with (Santrock, 2010) who concluded that people choose occupations that are consistent with the way they see themselves, that reflect their interests, values, and strengths and that Self-concept changes with age and people continue to discover things themselves well into adulthood.

Research Question 2: What are the challenges encountered by students at Wa Senior High Technical School in their choice of careers?

Some of aspect of the questionnaire was to gather data on challenges encountered by students in their choice of career. This is what Table 12 presents.

Table 12

Challenges Students Encountered in Their Choice of Careers

\begin{tabular}{|c|c|c|c|c|c|c|c|}
\hline Factors & $\begin{array}{c}\text { Strongly } \\
\text { Agree }\end{array}$ & Agree & $\begin{array}{l}\text { Not } \\
\text { Sure } \\
\end{array}$ & Disagree & $\begin{array}{l}\text { Strongly } \\
\text { Disagree }\end{array}$ & (F) & $\%$ \\
\hline $\begin{array}{l}\text { 1. Lack of career guidance } \\
\text { services }\end{array}$ & $8(10.0 \%)$ & $8(10.0 \%)$ & - & - & - & 16 & 20.0 \\
\hline $\begin{array}{l}\text { 2. Inadequate career } \\
\text { information }\end{array}$ & $10(12.5 \%)$ & $5(6.0 \%)$ & - & - & - & 15 & 18.5 \\
\hline 3. Influence of friends/peers & - & - & $4(5.0 \%)$ & $4(5.0 \%)$ & - & 8 & 10.0 \\
\hline 4. Influence of parents & $10(12.5 \%)$ & $4(5.0 \%)$ & - & - & - & 14 & 17.5 \\
\hline 5. Influence of teachers & - & - & - & $2(2.5 \%)$ & $4(5.0 \%)$ & 6 & 7.5 \\
\hline 6. Parents occupation & $2(2.5 \%)$ & $7(8.75 \%)$ & - & - & - & 9 & 11.25 \\
\hline
\end{tabular}




$\begin{array}{lllllll}36 & 30 & 4 & 6 & 4 & 80 & 100\end{array}$

Source: Field Data (2016)

On the issue of challenges encountered in career decision making among students in the Senior High School, the study made it clear in table 12 above that 16 students representing (20.0\%) strongly agreed and agreed that lack of career guidance service impede their career decision making, 15 students representing (18.5\%) strongly agreed that inadequate career information impedes students career decision making in the Senior High School, 8 students representing $(10.0 \%)$ of respondents neither agreed nor disagreed to the assertion their peers/friends impede their career decision making process, 14 students representing (17.5\%) of the respondents strongly agreed and agreed that parental influence impedes their career decision making, 6 students representing (7.5\%) of respondents strongly disagreed that influence of teachers have any negative impact on their career decision making, 9 students representing $(11.25 \%)$ of respondents agreed that parents occupation impedes students career decision making. Also 12 students representing (15.0\%) of respondents strongly agree and agree that lack of profession counseling coordinators impedes career decision making among Senior High School students.

Looking the finding, it could be deduced that lack of career guidance services, inadequate career information and parental influence are the key factors that impede students career decision making. On the issue of lack of career guidance services, it was evidenced that the school has no professional counselor as their coordinator to undertake guidance programmes in the school.

The respondents also mentioned that it was important for teachers to be trained to assist students in their career choice because teachers knew the academic strengths, weakness, talents and interest of students. Surprisingly, respondents suggested that teachers were not currently doing well in career counselling activities and those who tried to assist students do not give them the right training and information.

Again, the results established that, due to the lack of career information amongst students, they were likely to be discriminated upon by the job market as employers want candidates with readily acquired skills to avoid wasting resources on training. The challenges faced by students according to teachers in making their career choice include family influence, peer pressure, lack of career guidance services, unavailability of jobs and unawareness of the requirement of choice of career, the problem of identifying and knowing themselves, and lack of marketable skills.

\section{Research Question 3: What are the career guidance needs of the students of Wa Senior High Technical School?}

The third question was to establish the career guidance needs of students at the Wa Senior High Technical School as it is very important as by Ampofo (2017) who mentioned that, it is never too early to begin thinking about careers when in Senior High School and the relevant data are presented in Table 13 and 14 below.

Table 13

Career Guidance Needs of Students as Expressed by Students




\begin{tabular}{lll}
\hline Career information & 16 & 20 \\
Employment information & 14 & 17.5 \\
Interpersonal information & 13 & 16.25 \\
Educational needs & 11 & 13.75 \\
Self-understanding & 9 & 11.25 \\
Financial needs & 8 & 10 \\
Remuneration information & 5 & 6.25 \\
Study Habit & 4 & 5 \\
Total & $\mathbf{8 0}$ & $\mathbf{1 0 0}$ \\
\hline
\end{tabular}

Source: Field Data, 2016

It can be observed from Table 13 that, the career guidance needs of students in Wa Senior High Technical School under career information 16(20\%), employment information 14(17.5\%), interpersonal information 13(16.25\%) and educational needs 11(13.75\%) are more relevant to students than self-understanding $9(11.25 \%)$, financial needs $8(10 \%)$, remuneration information 5(6.25\%) and study habit 4(5\%). From Table 13, career information was the most prevalent career guidance needs of students and was closely followed by employment information. Interpersonal needs of students was third on the scale and the other students career guidance needs in order of importance are educational needs, self-understanding, financial needs, remuneration information and study habit.

\section{Career Guidance Needs of students as Expressed by Teachers}

Table 14 shows the career guidance needs as expressed by the adult population including teachers and guidance and counselling coordinator in the school and the relevant data are presented in Table 14 below.

Table 14

Career Guidance Needs of Students as Expressed by Teachers and Guidance Coordinator

\begin{tabular}{lll}
\hline Need & $(\mathbf{F})$ & $\mathbf{( \% )}$ \\
\hline Educational information & 10 & 23.3 \\
Study habits & 9 & 21 \\
Interpersonal information & 7 & 16.3 \\
Educational needs & 6 & 14 \\
Career needs & 5 & 11.6 \\
Self-understanding & 4 & 9.3 \\
Financial needs & 2 & 4.6 \\
\hline Total & $\mathbf{4 3}$ & $\mathbf{1 0 0}$ \\
\hline \multicolumn{2}{c}{ Source: Field Data, } & 2016
\end{tabular}

It can be seen from the results that the adults' population perceived educational information, study habits, interpersonal information, educational needs and career needs as the top five important career needs of students. In terms of percentages of the top five career needs, we have $10(23.3 \%)$ for educational information, $9(21 \%)$ for study habits, $7(16.3 \%)$ for interpersonal information, $6(14 \%)$ for educational needs and $5(11.6 \%)$ for career needs. 
On the part of teachers on career needs of students, they ranked the top five career needs of students as educational information, study habits, interpersonal information, educational needs and career needs. The study has, therefore, established that what students perceived as their career need was different from the views of teachers.

The views of teachers must be taken serious, because according to a study done on the comprehensive career needs of students in grades 7-12, the career planning needs that have been addressed in past career planning programs are representative of the needs that parents or other adults have found to be significant (Bernes, Magnusson, Poulsen, \& Pyne, 2002).

\section{Analysis of Teachers and Guidance and Counselling Coordinator Data}

Knowledge of Job information by SHS Graduate according to Guidance and Counselling Coordinator and Teachers

Most respondents explained that students were not aware of job information despite the fact that students were given books that showed various job opportunities that go with the kind of programme offered. Other respondents suggested that, they had never organised any guidance programme on job information for students. Some counsellors also mentioned that majority of students did not have any guidance on job requirements and occupational groups. This conclusion is consistent with a study by Lawer (2007) who found that majority of young people leave school with only a vague knowledge of employment opportunities and with little insight as to the most appropriate career direction for their abilities, interests and personality.

\section{How Frequent Career Choice Programmes were organised for Students}

Almost all the respondents mentioned that career choice programmes were hardly organised for students. They mentioned that they only gave student books on the various job opportunities that go with the programmes students offered and occasionally organised seminars on programmes and their corresponding job opportunities for students. According to the Organisation for Economic Cooperation and Development (OECD) (2004), despite the importance of career guidance in preventing inflows into unemployment particularly long term unemployment, yet career guidance services within the public sector are undeveloped.

\section{Reasons for Training Teachers in the Basic Schools to Assist Students to Select their Occupations}

The reasons given by respondents for training basic school teachers to assist students in their occupation were many. Some mentioned that since they knew the strengths of students in terms of subject area, they trained basic school teachers to assist students is in the right direction or path Others also mentioned that, training teachers was very important because they were best fit to guide students in choosing their career since they knew the interest of students' best than any other person like parents. Others also mentioned that teachers' contacts with students gave them the opportunity to identify the talents of students and as a result were best fit to guide students in choosing their careers. These reasons for training teachers are very important in preparing adolescents from diverse backgrounds for the career choices they will have to make upon graduation is a huge responsibility that is regularly filled by the school counsellor(s) (Kankam, 2000). 


\section{Teachers' Performance on Career Guidance and the Right Training of Students in Career Choice}

Majority of respondents explained that, teachers were not doing well in career guidance at all. They mentioned that teachers did not initiate any career guidance efforts or programmes but only relied on the initiatives and efforts of school administrators. Even the few teachers who tried to guide students on career choice did not give the right training to the students since they themselves lacked the required career guidance information and in the end, the student was denied the right information to guide him or her to make a meaningful career choice. From the study, it is clear that teachers' performance on career counselling was very poor despite the fact that the demand for career guidance services exceeds its supply as posited by (OECD, 2004).

\section{Students' Discrimination in the Job Market due to Current Training}

Unexpectedly, all respondents agreed that because of lack of career information by students, they were mostly discriminated against either because they applied for the wrong job or they did not qualify at all as employers wanted candidates with readily acquired skills to avoid wasting of resources on training sessions.

\section{Respondents' Views on Problems Students Encounter in Making their Choices}

The challenges encountered by students in making their career choice as expressed by counsellors and administrators include family influence, peer pressure, lack of career guidance services, unavailability of jobs and unawareness of the requirement of choice of career, the problem of identifying and knowing themselves, and lack of marketable skills. These challenges made it difficult for students in making their career choice according to respondents.

These views of students are consistent with a study by Lawer (2007), who researched on assessing the effectiveness of career guidance in Senior High Schools in Kumasi Metropolitan and concluded that majority of students were not aware of major occupation groups in Ghana, knowledge of training and qualification necessary for employment in the various occupations, conditions of work, earning and other rewards of occupation, and did not have better understanding of their career interest, aptitudes and abilities.

\section{SUMMARY OF MAJOR FINDINGS}

The first research question was to examine the factors that influence choice of careers among Wa Senior High Technical School students. The study found that among all the three factor groups (Extrinsic factors, Intrinsic factors and Inter-Personal factors) contributing to student career choice, the five top most important factors according to ranking are perception of colleagues/peer pressure, teachers' influence, societal perceptions, availability of further training and occupational security. A closer look at the top five factors indicates that they are related to interpersonal factors and extrinsic factors.

The second research question investigated on the challenges encountered by students at Wa Senior High Technical School in their choice of careers. The study found that, lack of career guidance services, inadequate career information and parental influence are the key factors that impede students' career decision making. Again the respondents expressed that career choice programmes were not frequently organised for students and they only provide career guide books for the students. Again the study found that the challenges faced by students according to teachers and counsellor in making their career choice include family influence, 
peer pressure, lack of career guidance services, unavailability of jobs and unawareness of the requirement of choice of career, the problem of identifying and knowing themselves, and lack of marketable skills. The study found differences on the views of students and the adult population on challenges encountered by students in their choice of careers.

Additionally, the study found that, due to the lack of career information amongst students, they are likely to be discriminated upon by the job market as employers want candidates with readily acquired skills to avoid wasting resources on training. The study further found that, to improve and sustain career guidance in schools, there was the need to appoint more Guidance and Counselling Coordinators in schools to counsel students and to organise career guidance programmes in the school frequently.

The importance of training teachers to assist students in their career choice was also established by the study as the adult population maintained that teachers knew the academic strengths, weakness, talents and interest of students. They, however, suggested that teachers are not currently doing well in career counselling activities and those who even try to assist students do not give them the right training and information.

The final research question was to identify the career guidance needs of the students of Wa Senior High Technical School. The study found that, career information was the most prevalent career guidance needs of students and was closely followed by employment information. Interpersonal needs of students was third on the scale and the other students career guidance needs in order of importance are educational needs, self-understanding, financial needs, remuneration information and study habit. Again the study found that, the career guidance needs as expressed by the adult population including teachers and guidance and counselling coordinator in the school are educational information, study habits, interpersonal information, educational needs and career needs.

\section{CONCLUSIONS}

This study identified the challenges facing Senior High Schools students in career choices in Ghana and concludes that career choice problems of Senior High School students includes family influence, peer pressure, lack of career guidance services, unavailability of jobs and unawareness of the requirement of choice of career, the problem of identifying and knowing themselves, and lack of marketable skills. Additionally, the study concludes that career choice programmes were not frequently organised for students and as a result students were likely to be discriminated against by the job market while teachers were not doing well when it comes to students' counselling.

This study also identified the career guidance needs of Senior High School students and concludes that the top five career guidance needs of students as expressed by students includes career information, employment information, interpersonal needs, educational needs and self-understanding. The career guidance needs of students include educational information, study habits, interpersonal information, educational needs and career needs.

The study also concludes that, the top five factors that influence students' choice of career were related to extrinsic and interpersonal factors and they were perception of colleagues/peer pressure, teachers' influence societal perceptions, availability of further training and occupational security and these factors were higher among older students and males as compared to younger students and females. 


\section{RECOMMENDATIONS}

Following from the findings and conclusions of this study, the researcher strongly recommends that the government of Ghana, through the Ministry of Education and the Ghana Education Service should adjust to the demands of contemporary times and introduce guidance and counselling as imperatives in the education of Ghanaian students especially at the basic school level. Guidance and Counselling units at the various schools should also be well-staffed with people who know what the field is about. Since career choice of students were related to extrinsic and interpersonal factors.

It is recommended that career education and guidance should be managed by Guidance and Counselling Coordinators in the basic schools to shape emotions and values of students in the formative years of their age to make a smooth transition from the basic school level to the Senior High School level and beyond.

All teachers teaching at Wa Senior High Technical School are to be equipped with counselling skills by the Ghana Education Service to enable them involve in career guidance activities of the school. The view that career education and guidance are often considered being the sole responsibility of the specialist career guidance staff, rather than the joint responsibility of all members of the teaching staff has to be discarded.

Government of Ghana as a matter of urgency has to enter into partnership with NGOs and other donor agencies to raise adequate fund to create job opportunities in Ghana to solve the problem of inadequate jobs reported by the guidance and counselling coordinator. It should also create enabling environment to encourage the private sector to create jobs to have lasting solution to unemployment problems in Ghana.

\section{Acknowledgements}

The researcher wants to thank the editorial board of Fair East Publishers, and also Antwi Abrefi Abigail (Law student at University of Professional Studies, Accra, Ghana) for her sound support and excellent contributions.

\section{Conflict of Interest Statement}

No conflict of interest has been declared by the author.

\section{Funding}

The researcher has not received any support for the publication of this paper.

\section{References}

Amanning, D. Y. (2009). Guidance Needs of Senior High School Students in Wassa Amenfi West and East Districts of the Western Region of Ghana. Unpublished Thesis, University of Cape Coast.

Ampofo, A. J. (2020). Challenges of Student Management Information System (MIS) in Ghana: A case study of University for Development Studies, Wa Campus. International Journal of Management \& Entrepreneurship Research, 2(5), 332-343.

Ampofo, A. J. (2020). The nature of mortgage repayment plans in Ghana. Finance \& Accounting Research Journal, 2(3), 91-104. 
Ampofo, A. J. (2020). Rural housing challenges in the Upper West Region of Ghana: A case study of Kulmasa. International Journal of Management \& Entrepreneurship Research, 2(4), 194-211.

Ampofo, A. J. (2020). Waste disposal management practices in selected senior high schools within the Wa Municipality of Ghana. International Journal of Management \& Entrepreneurship Research, 2(4), 273-290.

Ampofo, A. J. (2020). Implications of poor waste disposal management practices on senior high schools within the Wa Municipality of Ghana. International Journal of Applied Research in Social Sciences, 2(3), 53-70.

Ampofo, A. J. (2020). Constraints factors to maintenance of government Senior High School buildings in Wa Municipal. International Journal of Management \& Entrepreneurship Research, 2(3), 139-160.

Ampofo, A. J. (2020). Contributions of the hospitality industry (hotels) in the development of Wa. International Journal of Advanced Economics, 2(2), 21-38.

Ampofo, A. J., \& Acheampong, B. (2019). Carrier decisions of Kadjebi Asato Senior High School Students and their choice of academic programmes: Lambert Academic Publishing.

Ampofo, A. J. (2019). Reading difficulties among class six pupils of Wa Basic School Complex: Lambert Academic Publishing.

Ampofo, A. J. (2019). Performance management and appraisal in improving teachers quality: Lambert Academic Publishing.

Ampofo, A. J. (2017). Community and parental influence on Senor High School (SHS) student's career choice: Lambert Academic Publishing.

Attieku, B., Dorkey, T., Marfo-Yiadom, E. \&Tekyi, K. (2006). Business managementGABET series (1st ed.). Cape Coast: Nyakow Printing Press.

Barker, J. (2000). School counselors' perceptions of required workplace skills and career development competencies. Professional School Counseling, 4(2), 134-139.

Bernes, K., Magnusson, K., Poulsen, J., \& Pyne, D. (2002). A description of junior high and Senior High School students' perceptions of career and occupation. Guidance \& Counseling, 17(3), 67-72.

Cob, N. J. (2001). Adolescence continuity, change and diversity (4th ed.). London: Mayfield Publishing Company.

Kankam, G. \& Onivehu, A. (2000). Principles and practice of guidance and counselling. Accra: K"N" A.B Ltd.

Lawer, T. D. (2007). Assessing the effectiveness of career guidance in SSS in Kumasi Metropolitan. Winneba: University of Education (Unpublished M. Phil Dissertation).

OECD. (2004) Career Guidance: A Handbook for Policy Makers, Paris.

Olson, E. M (2004). An Examination of University Students' Perceptions of Their Secondary Career Guidance Programs. MA Thesis, University of Wisconsin-Stout.

Pittenger, D. J. (2003). Behavioural research: Design and analysis. America: McGrawHill.

Pearson Education Limited (2007). Longman dictionary of contemporary English (New Edition). China: GCC.

Santrock, J. W. (2001). Adolescence ( $8^{\text {th }}$ ed.). New York: McGraw-hill higher Education. 
Sultana, R. G. (2004), Guidance Policies in the Knowledge Economy. Trends, Challenges and Responses Across Europe. A Cedefop Synthesis Report, Cedefop Panorama seriesNo.85, Office for Official Publications of the European Commission, Luxembourg.

Watts, A.G. \& Fretwell D. H. (2004), Public Policies for Career Development. Case Studies and Emerging Issues for Designing Career Information and Guidance Systems in Developing and Transition Economies, The World Bank, Washington. 